\title{
Endoplasmic reticulum stress as a key mechanism in stunted growth of seawater rainbow trout (Oncorhynchus mykiss)
}

\author{
Bernat Morro', Richard Broughton', Pablo Balseiro ${ }^{2,3}$, Sigurd O. Handeland ${ }^{2,3}$, Simon Mackenzie 1,2,
} Mary K. Doherty ${ }^{4}$, Phillip D. Whitfield ${ }^{4,5}$, Munetaka Shimizu ${ }^{6}$, Marnix Gorissen ${ }^{7}$, Harald Sveier ${ }^{8}$ and Amaya Albalat ${ }^{*}$

\begin{abstract}
Background: Rainbow trout (Oncorhynchus mykiss) is a salmonid species with a complex life-history. Wild populations are naturally divided into freshwater residents and sea-run migrants. Migrants undergo an energydemanding adaptation for life in seawater, known as smoltification, while freshwater residents display these changes in an attenuated magnitude and rate. Despite this, in seawater rainbow trout farming all fish are transferred to seawater. Under these circumstances, weeks after seawater transfer, a significant portion of the fish die (around 10\%) or experience growth stunting (GS; around 10\%), which represents an important profitability and welfare issue. The underlying causes leading to GS in seawater-transferred rainbow trout remain unknown. In this study, we aimed at characterising the GS phenotype in seawater-transferred rainbow trout using untargeted and targeted approaches. To this end, the liver proteome (LC-MS/MS) and lipidome (LC-MS) of GS and fast-growing phenotypes were profiled to identify molecules and processes that are characteristic of the GS phenotype. Moreover, the transcription, abundance or activity of key proteins and hormones related to osmoregulation (Gill $\mathrm{Na}+, \mathrm{K}+-$ ATPase activity), growth (plasma IGF-I, and liver igf1, igfbp 16, ghr1 and ctsI) and stress (plasma cortisol) were measured using targeted approaches.

Results: No differences in Gill Na+, K+-ATPase activity and plasma cortisol were detected between the two groups. However, a significant downregulation in plasma IGF-I and liver igf1 transcription pointed at this growth factor as an important pathomechanism for GS. Changes in the liver proteome revealed reactive-oxygen-speciesmediated endoplasmic reticulum stress as a key mechanism underlying the GS phenotype. From the lipidomic analysis, key observations include a reduction in triacylglycerols and elevated amounts of cardiolipins, a characteristic lipid class associated with oxidative stress, in GS phenotype.
\end{abstract}

Conclusion: While the triggers to the activation of endoplasmic reticulum stress are still unknown, data from this study point towards a nutritional deficiency as an underlying driver of this phenotype.

\footnotetext{
* Correspondence: amaya.albalat@stir.ac.uk

${ }^{1}$ Institute of Aquaculture, University of Stirling, Stirling, UK

Full list of author information is available at the end of the article
}

(c) The Author(s). 2021 Open Access This article is licensed under a Creative Commons Attribution 4.0 International License, which permits use, sharing, adaptation, distribution and reproduction in any medium or format, as long as you give appropriate credit to the original author(s) and the source, provide a link to the Creative Commons licence, and indicate if changes were made. The images or other third party material in this article are included in the article's Creative Commons licence, unless indicated otherwise in a credit line to the material. If material is not included in the article's Creative Commons licence and your intended use is not permitted by statutory regulation or exceeds the permitted use, you will need to obtain permission directly from the copyright holder. To view a copy of this licence, visit http://creativecommons.org/licenses/by/4.0/ The Creative Commons Public Domain Dedication waiver (http://creativecommons.org/publicdomain/zero/1.0/) applies to the data made available in this article, unless otherwise stated in a credit line to the data. 
Keywords: Aquaculture, Insulin-like growth factor-I, Reactive oxygen species, Runt, Pathology, Oxidative stress, Salmonid, Smoltification, Steelhead

\section{Background}

Industrialised intensive aquaculture is a more recent form of animal production than stockbreeding of terrestrial animals (i.e. poultry, cattle and pigs) and, by comparison, has had relatively few years to selectively breed the most desirable attributes [1]. Fish breeding programs rely heavily on advances in reproductive and molecular techniques to accelerate the selection of desirable traits [2]. The relatively low degree of domestication, particularly in some aquatic species, provides scientists with the opportunity to study unwanted commercial phenotypes that may not be present in the future. With the identification of the cause(s) of such phenotypes, their development could be prevented. For production species, fast growth is one of the main desirable attributes. Slow or stunted growth, on the other hand, is a phenotype that delivers negative impacts on production profitability, sustainability, and more importantly on animal welfare [3].

Rainbow trout (Oncorhynchus mykiss) is a salmonid species with a unique life-history. Wild populations are naturally divided into freshwater residents, which do not migrate to seawater, and sea-run migrants. The latter undergo an energy-demanding rheostatic process that prepares the organism for life in seawater while still in freshwater (i.e. smoltification), while freshwater residents display an attenuated magnitude and rate of these changes $[4,5]$. The drivers towards either life history are largely unknown. Efforts to produce a strain with a single phenotype, either selecting the sea-run $[4,6,7]$ or the freshwater-resident [8], could only increase the proportion of the desired phenotype. Production of seawater transferred-rainbow trout is still relatively small but both investment and production have increased steadily in recent years [9]. The animals grown in these production systems are only a few generations away from freshwater-farmed rainbow trout, which were selected for their performance in freshwater systems. Under these circumstances, a persistent problem has affected this sector: shortly after seawater transfer, a portion of the animals (around 10\%) die, and another portion (around $10 \%)$ experience reduced growth, a marked decrease in condition factor, and poor welfare $[10,11]$. These animals are known as growth-stunted (GS) or runts (in Norwegian pinne, meaning stick).

Few published studies have investigated the GS seawater-transferred rainbow trout phenotype. Two studies found nematode infections in a small proportion of the GS rainbow trout: Roiha et al. [12] detected it in 5 runts out of 178 discarded fish and not in harvest quality fish, and Skov et al. [13] detected it in 9.5\% of the runts and $2.1 \%$ of the harvest quality fish. This was likely due to the reported feeding habits of the GS fish, which consumed more small fish, crustaceans and biofouling species than their healthier counterparts [13], and not an underlying cause of GS development. Previous studies identified a freshwater rainbow trout phenotype, as also seen in other salmonid species [14-16], that occurs in both aquaculture and laboratory conditions and presents stunted growth and reduced condition factor $[17,18]$. Studies have shown that while reduced food intake is an important factor for the development of this phenotype in rainbow trout [18, 19], fundamental physiological traits such as a higher standard metabolic rate are key intrinsic drivers in brown trout (Salmo trutta) [15]. Other studies have linked GS to subordinate behaviour, with subordinate fish exhibiting higher post-stress plasma cortisol levels and lower stressor avoidance [20, 21]. From a metabolic perspective, subordinate fish rely on $\beta$-oxidation of circulating free fatty acids rather than on triacylglycerides (TAGs) for energy [22]. Moreover, differences in carbohydrate metabolism in subordinate fish include a lower hepatic glycogen content, higher gluconeogenic potential [23-25] and higher plasma glucose levels [18, 26, 27]. From a protein perspective, results so far have been inconclusive with no significant changes reported in liver protein levels, with only moderate, but not significantly different, aspartate aminotransferase and alanine aminotransferase activities detected [18]. These listed mechanisms may be relevant to the GS phenotype in seawater-transferred rainbow trout but, interestingly, the problem at hand occurs only after an artificial and forceful seawater transfer of the fish.

Several explanations, such as increased stress, subordinate social status, incomplete smoltification or fasting are possible causes. In cases like this, the initial characterisation of the phenotype can be the way forward, providing a holistic view of the underlying mechanisms that lead to a condition [28-30]. This is where -omics technologies exceed, measuring the abundance of large numbers of posteriorly annotated biomolecules (i.e. transcripts, proteins, metabolites, lipids, etc.) of a sample in an untargeted manner. With this information, it is possible to pinpoint the involved pathways before moving onto a targeted approach to study them in detail. In similar cases within both humans and other animal species, -omics approaches have been successfully used, with both proteomic and lipidomic studies having been used to assess the effects on liver tissue of differential feeding [31-33], stress [34], and disease [35, 36], among others. 
As a target tissue, the liver, due to its central role in energy storage and mobilization, is ideal as it should reflect differences in energy balance and metabolism [37]. Liver pathologies like hepatic steatosis (i.e. fatty liver) have been linked to loss of appetite and dwarfism in animals like cattle and horses $[38,39]$, which in turn have been attributed to endoplasmic reticulum (ER) stress $[40,41]$. The ER is central to the processes of energy production and protein synthesis. ER stress prevents the correct function of the organelle and it is intrinsically linked with the dysregulation of lipid metabolism [41]. One of the main consequences of ER stress is an accumulation of mis-folded proteins in the ER lumen and impaired protein glycosylation. Folding depends on the correct function of lectins like calreticulin and calnexin [42], while other proteins like Heat Shock Protein 90 (HSP90) stabilize the system [43]. ER stress is closely related to oxidative stress and redox homeostasis [44]. ER stress in hepatic disorders like steatosis have been linked to abnormally regulated proteins such as glycine $\mathrm{N}$ methyltransferase [45], catalase [46], and alpha-2macroglobulin [47]. Pathogens can also drive ER stress. For instance, the salmonid pathogens Francisella spp. have been shown to disrupt the transcription of enzymes involved in glycosylation or deglycosylation [48]. Currently, there is no data to support whether the GS phenotype is linked to oxidative and ER stress although these processes have been linked to several metabolic disorders that can negatively affect health and growth $[49,50]$.

The aim of this study was to characterise the GS phenotype using targeted and untargeted approaches. To this end, the liver proteome (liquid chromatography - tandem mass spectrometry (LC-MS/MS)) and lipidome (liquid chromatography - mass spectrometry (LC-MS)) of GS and FG phenotypes were profiled to pinpoint molecules and processes that are characteristic of the GS phenotype. Moreover, the transcription of several genes (insulin-like growth factor 1 (igf1), insulin-like growth factor binding protein $1 b$ (igfbp1b), growth hormone receptor 1 (ghrl) and cathepsin L $(c t s l)$, as well as abundance (plasma IGF-I and cortisol) and activity (Gill $\mathrm{Na}^{+}, \mathrm{K}^{+}$-ATPase (NKA)) of key proteins and hormones related to osmoregulation (NKA activity), growth (plasma IGF-I, igf1, igfbp1b, ghrl and $c t s l$ ) and stress (plasma cortisol) were analysed using targeted approaches.

\section{Results}

\section{Seawater tolerance in FG and GS fish}

NKA activity values after 9 weeks in seawater were not related to GS development as no significant differences among FG and GS groups $(p=0.60, \mathrm{df}=32, \mathrm{t}=0.53)$ were observed. Values for both groups were $2.6 \pm$ $0.30 \mu \mathrm{mol}$ ADP mg protein ${ }^{-1} \mathrm{~h}^{-1}$ on average (Fig. 1).

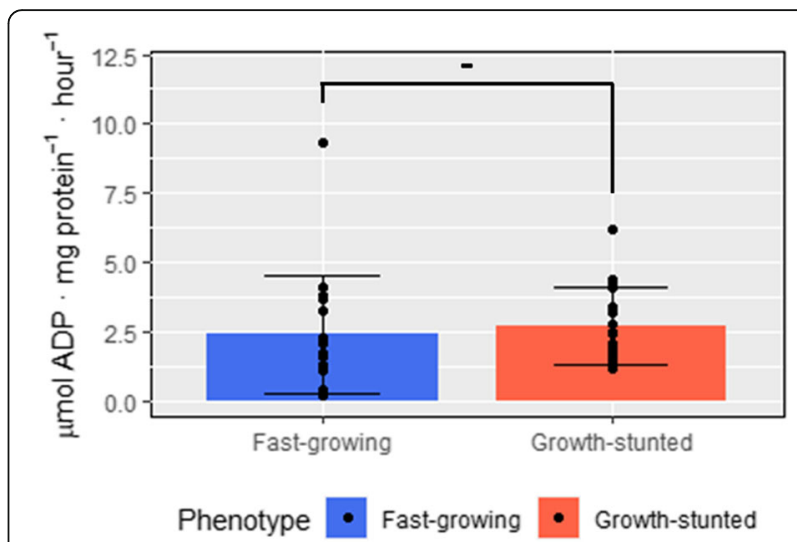

Fig. 1 Gill Na+, $\mathrm{K}+-$ ATPase activity in FG and GS fish. Samples were taken after 9 weeks in seawater $(n=17)$

\section{Plasma cortisol in FG versus GS fish}

Plasma cortisol levels showed no significant differences among phenotypes in either freshwater $(p=0.47, \mathrm{df}=28$, $\mathrm{t}=0.73)$ or seawater $(p=0.44, \mathrm{df}=58, \mathrm{t}=0.78)$. However, cortisol levels were significantly higher when fish were in freshwater (average of $76.0 \pm 10.67 \mathrm{ng} \mathrm{ml}^{-1}$ ) compared to seawater (average of $20.8 \pm 4.19 \mathrm{ng} \mathrm{ml}^{-1}$ ) $(p<0.0001, \mathrm{df}=88, \mathrm{t}=5.76)$ (Fig. 2$)$.

\section{Growth-related parameters in FG versus GS fish}

Circulating plasma IGF-I levels showed no significant differences among phenotypes in freshwater $(p=0.18$, $\mathrm{df}=14, \mathrm{t}=1.46)$ but did after 9 weeks in seawater $(p<$ $0.01, \mathrm{df}=13, \mathrm{t}=3.09$ ) (Fig. 3). This significant difference was due to a significant increase for FG $(\mathrm{p}<0.01, \mathrm{df}=7$, $\mathrm{t}=3.76$ ), while plasma IGF-I levels did not vary significantly from freshwater to seawater for GS $(p=0.63, \mathrm{df}=$ $7, \mathrm{t}=0.50)$.

After 9 weeks in seawater, concordantly with plasma IGF-I abundance, liver igf1 transcription was higher in FG than in GS $(p<0.01, \mathrm{df}=14, \mathrm{t}=3.99)$. On the other hand, while not significant for igfbp1b, there was weak

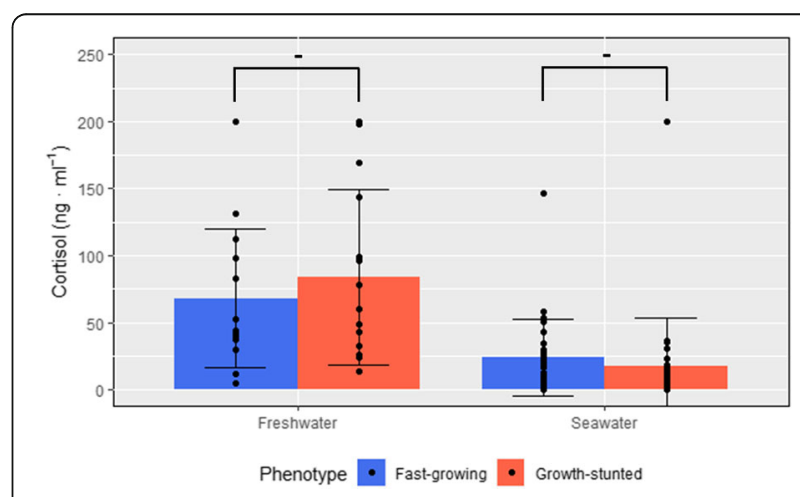

Fig. 2 Plasma cortisol levels in FG and GS fish. Samples were taken prior (left, $n=15$ ) and 9 weeks after (right, $n=30$ ) seawater transfer 


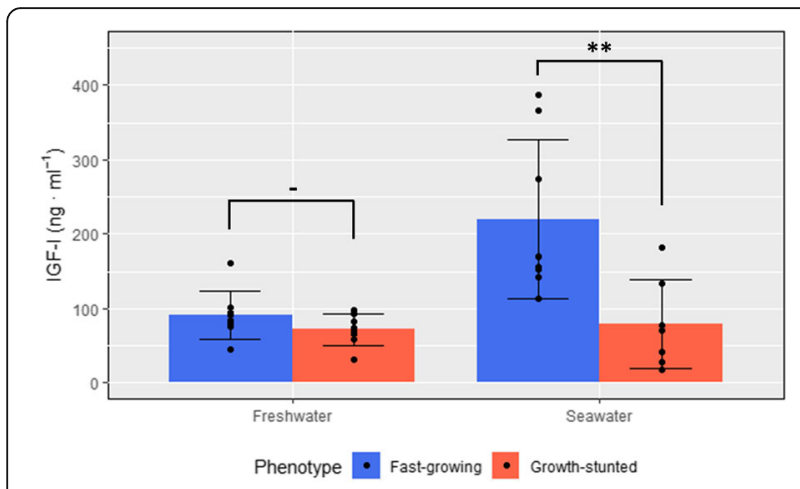

Fig. 3 Circulating IGF-I abundance in FG and GS fish. Samples were taken prior (left) and 9 weeks after (right) seawater transfer $(n=8)$

evidence (i.e. $0.05<p$-value $<0.1$ ) indicating that its transcription might be higher in GS $(p=0.07, \mathrm{df}=14$, $\mathrm{t}=1.94)$. For $\operatorname{ghrl}(p=0.10, \mathrm{df}=14, \mathrm{t}=1.73)$ and ctsl transcription $(p=0.39, \mathrm{df}=14, \mathrm{t}=0.90)$, no differences were observed (Fig. 4).

\section{Liver proteome analysis}

The protein fraction in the liver of FG fish was significantly lower $(14.6 \% \pm 0.75)$ than in GS fish $(17.5 \% \pm 1.05)$ $(p<0.01, \mathrm{df}=8, \mathrm{t}=4.94)$. After MS analysis of TMT labelled liver samples, a total of 540 peptides were detected (Additional file 1). Of those, 299 peptides were uniquely assigned to proteins and used for quantification. These peptides were mapped onto 132 quantified proteins.
In total, 19 differential proteins (q-value $<0.05$ ) were detected when comparing the liver proteome of GS and FG (Fig. 5). These proteins were assigned functionally to translation, redox homeostasis, oxygen transport, stress response, and transport and metabolism of carbohydrates and lipids. Among upregulated differential proteins in the GS phenotype there were a number of critical protein chaperones previously reported to be associated with reactive oxygen species (ROS) mediated ER stress: calreticulin, protein disulphide isomerases (PDI; I, II and III), HSP90- $\alpha 1$, alpha-2-macroglobulin. Other proteins associated with the ER and involved in the translocation of secretory proteins (translocating chain-associated membrane protein) or involved in providing reducing equivalents to maintain adequate levels of reductive cofactors in the ER (GDH/6PGL endoplasmic bifunctional protein) were also upregulated. On the other hand, downregulated differential proteins in the GS phenotype included catalase (I and II), a crucial antioxidant enzyme, the inhibition of which has been reported under ER stress conditions, and other proteins also reported to be closely linked to ER stress and redox homeostasis such as Glycine N-methyltransferase or involved in lipid and energy homeostasis, such as annexin, sterol carrier protein 2 (SCP-2) and malate dehydrogenase.

\section{Liver lipidome analysis}

Lipid levels in the liver of FG fish were not significantly different $(15.4 \pm 2.87 \%)$ to levels in GS fish $(13.8 \pm 0.97 \%)$

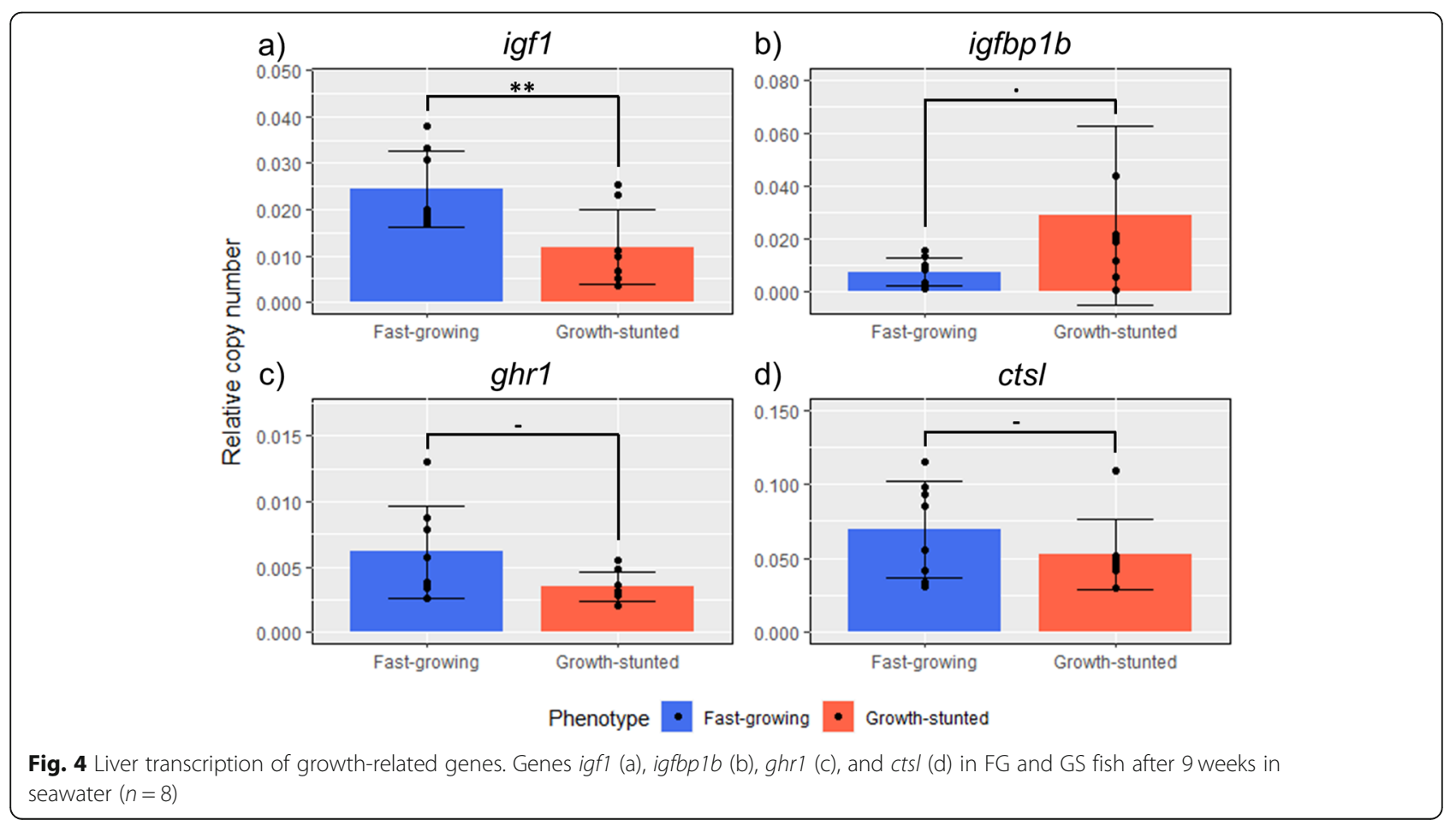




\begin{tabular}{|c|c|c|c|c|c|c|c|c|c|c|}
\hline \multicolumn{5}{|c|}{ Fast-growing } & \multicolumn{4}{|c|}{ Growth-stunted } & \multirow[b]{2}{*}{ Accession } & \multirow[b]{2}{*}{ Protein name } \\
\hline 1 & 2 & 3 & 4 & 5 & 1 & 2 & 3 & 4 & & \\
\hline & & & & & & & & & 095479 & GDH/6PGL endoplasmic bifunctional protein \\
\hline & & & & & & & & & Q6UD79 & Calreticulin \\
\hline & & & & & & & & & P01023 & Alpha-2-macroglobulin \\
\hline & & & & & & & & & A0A060X559 & Protein disulfide-isomerase (I) \\
\hline & & & & & & & & & A0A060W539 & Protein disulfide-isomerase (II) \\
\hline & & & & & & & & & A0A060WQP1 & Protein disulfide-isomerase (III) \\
\hline & & & & & & & & & Q90474 & Heat shock protein HSP 90-alpha 1 \\
\hline & & & & & & & & & A0A060W2P7 & Dolichyl-diphosphooligosaccharide-protein glycosyltransferase 1 \\
\hline & & & & & & & & & C1BG76 & $40 \mathrm{~S}$ ribosomal protein $\mathrm{S} 13$ \\
\hline & & & & & & & & & A0A1S3LI61 & Translocating chain-associated membrane protein \\
\hline & & & & & & & & & P51124 & Granzyme M \\
\hline & & & & & & & & & A0A060VXL3 & Annexin \\
\hline & & & & & & & & & AOA060YE44 & Poly [ADP-ribose] polymerase \\
\hline & & & & & & & & & A0A060VZR8 & Malate dehydrogenase \\
\hline & & & & & & & & & A0A060W7L7 & Catalase (I) \\
\hline & & & & & & & & & A0A060X782 & Catalase (II) \\
\hline & & & & & & & & & A0A060XET2 & Glycine N-methyltransferase \\
\hline & & & & & & & & & P22307 & Sterol carrier protein 2 \\
\hline & & & & & & & & & Q98974 & Alpha-globin IV \\
\hline
\end{tabular}

Fig. 5 Heatmap of protein abundance for 19 differential proteins between FG and GS liver samples $(n=5)$. Accession and protein name are retrieved from Uniprot (uniprot.org). Colour goes from white (less abundant) to dark red (more abundant) and each row is scaled independently

$(p=0.60, \mathrm{df}=8, \mathrm{t}=0.54)$. Lipidomics analysis of liver samples returned 6456 and 2756 lipid features in positive and negative modes, respectively. OPLS-DA analysis (Suppl. Fig. 1, Additional File 2) revealed that neutral lipids, specifically TAGs, as well as ceramides and a cholesteryl ester were found to be the main drivers in separating the FG fish from the GS fish. TAGs ranged from 52 to 60 carbon moieties, however the 56-60 carbon TAGs appeared to dominate, with a wide range of unsaturation levels, again ranging from 1 to 9 double bonds. With regards to peak abundance, TAG peak areas were found to be highest with peak areas in the $10^{6}$ and $10^{7}$ ion count range. However, care must be taken with regard to inter-lipid comparisons, as a fold change quantitation method was used, which is not amenable to absolute lipid quantitation. Six unknown features (unnamed Lipid ID rows plus LMS0601CI08 in Fig. 6) were also detected which exhibited large fold changes, albeit with much lower abundances (Fig. 6, Additional file 2).

In general, the phospholipids which distinguish the GS condition tended to be larger at 44 carbons in length, as well as being more unsaturated, containing on average 10 double bonds. There was also some compound identity ambiguity, based on mass accuracy alone, which yielded either phosphatidyl serine or inositol-based sphingolipids, with these compounds generally being more abundant in the FG fish.

In total, 55 differential lipids were significantly higher in FG (fold change $>1.5$; q-value $<0.05$ ) compared to
GS. The most significant changes in terms of numbers (24) and the greatest fold changes (ranging from 2.8 to 14.8) were observed in TAG, with most TAGs experiencing a fold change greater than 5 in the FG fish (Fig. 6). On the other hand, in GS liver, 39 lipids were significantly more abundant (fold change $<-1.5$; q-value < $0.05)$, all of which were phospholipids; phosphatidylcholine (PC; 15), phosphatidylethanolamine (PE; 7), phostidylserine (PS; 4) and cardiolipins (CL, 4) (Fig. 7). In fact, both conditions demonstrated fluctuations within the main classes of phospholipid, including PC, PE and PS, with PG 44:12 only detected in FG fish and phosphatidylinositol (PI) 38:6 and 36:4 only detected in GS fish. The phospholipids in general were elevated in the GS fish, as illustrated by the approximately 2.5 -fold increase in the number of phospholipids. GS fish also produced elevated amounts of CL, which was a characteristic lipid class associated with this phenotype.

\section{Discussion}

Seawater-transferred rainbow trout farming is a developing industry, which has experienced a strong increase in production during the last three decades [9]. However, the incidence of GS fish has hindered its economic growth and is an animal welfare concern. The cause of the development of this unwanted phenotype remains unknown. Understanding the underpinning metabolic traits that characterise this phenotype could be the first step towards optimized rearing strategies and feeding 


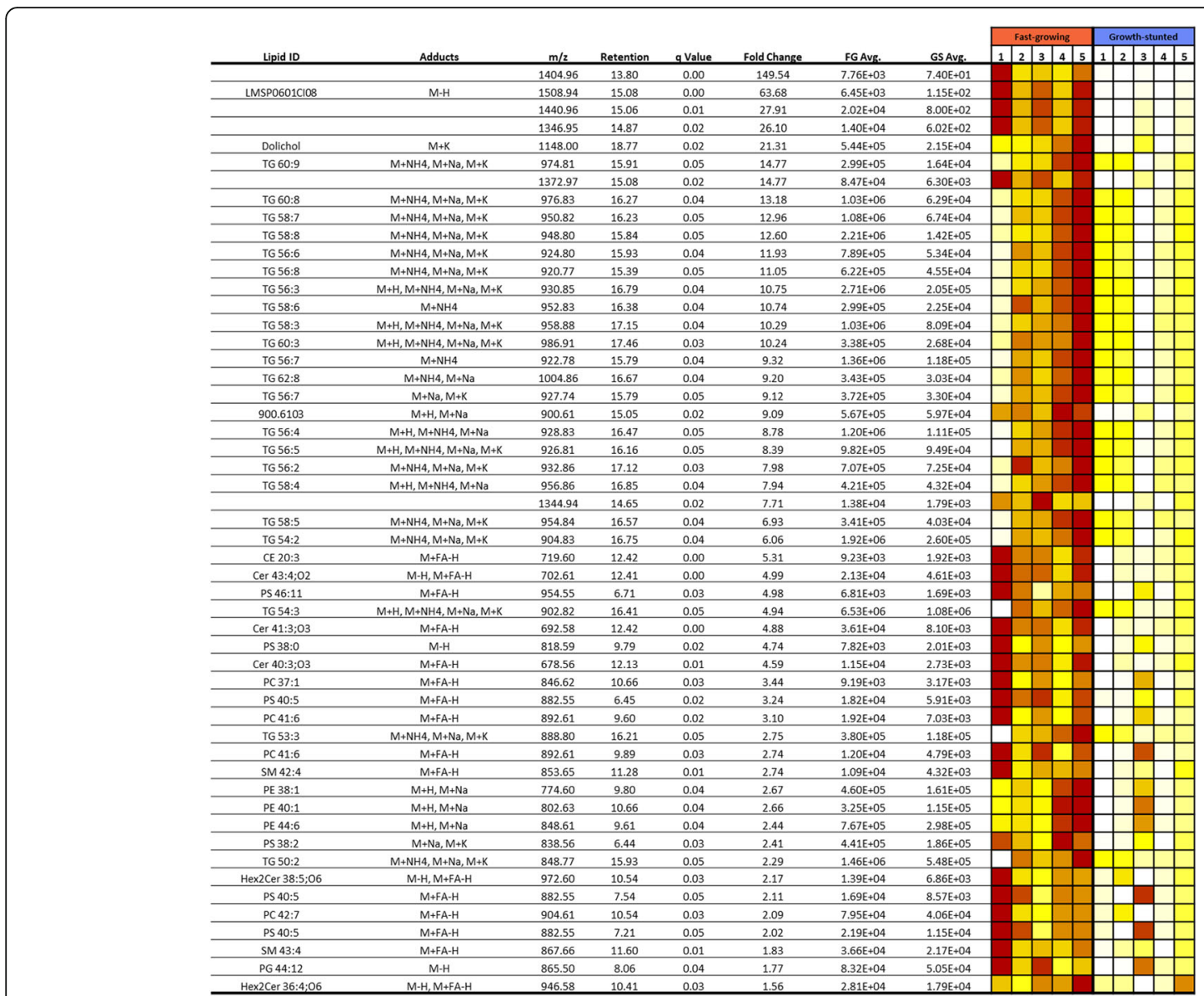

Fig. 6 Significantly higher lipids in the fast-growing phenotype $(n=5)$. GS: Growth-stunted, FG: Fast-growing. Abundance values are based on normalised ion counts. Colour goes from white (less abundant) to dark red (more abundant) and each row is scaled independently. Retention is expressed in minutes

protocols that decrease the incidence of GS. To this end, untargeted -omics approaches were used to study the liver proteome and lipidome of GS fish compared to FG fish, while targeted approaches were employed to measure smoltification status (NKA activity), growth-related (plasma IGF-I abundance and liver igfl, igfbp $1 b, g h r$, and ctsl transcription) and stress-related parameters (plasma cortisol).

Since growth is the attribute that most clearly distinguishes GS and FG fish, it would be expected that growth-related molecular drivers differ between the two phenotypes. As determined by a genome-wide association studies [51, 52], somatic growth is polygenic trait in rainbow trout. It is associated to single-nucleotide polymorphisms in several candidate genes including genes involved in development processes, growth factors, and bone tissue and nutrient metabolism. It is highly likely that the GS condition is also genetically determined, which would justify breeding programs to reduce the appearance of GS. Some genes and proteins are classically measured as determinants of growth. IGF-I is a peptide hormone that promotes growth in fish, as is IGF-II [53-55], along with growth hormone and its receptor GHr1, among others. Among the IGFBPs (1 to 6) present in rainbow trout, IGFBP1b was of especial interest as it inhibits the binding of IGF-I to its receptor and represses growth [56, 57]. Both IGFBP1b and CTSL, an endopeptidase, are induced under catabolic conditions $[58,59]$. Indeed, differences between the two phenotypes were found in some of these growth-regulatory molecules. No evidence to confirm changes in the expression of $g h r 1$, igfbplb or ctsl was obtained, but the involvement of IGF-I was demonstrated. IGF-I was significantly lower in GS fish at both plasma and liver transcription levels. These results reiterate the importance of the somatotropic axis in the regulation of growth and show their involvement in the development of GS [60]. Moreover, while plasma IGF-I increased in FG fish during their time in seawater, levels in GS did not vary. This suggests that GS development might be associated to suboptimal seawater adaptation, which may trigger the development of this phenotype after animals are 


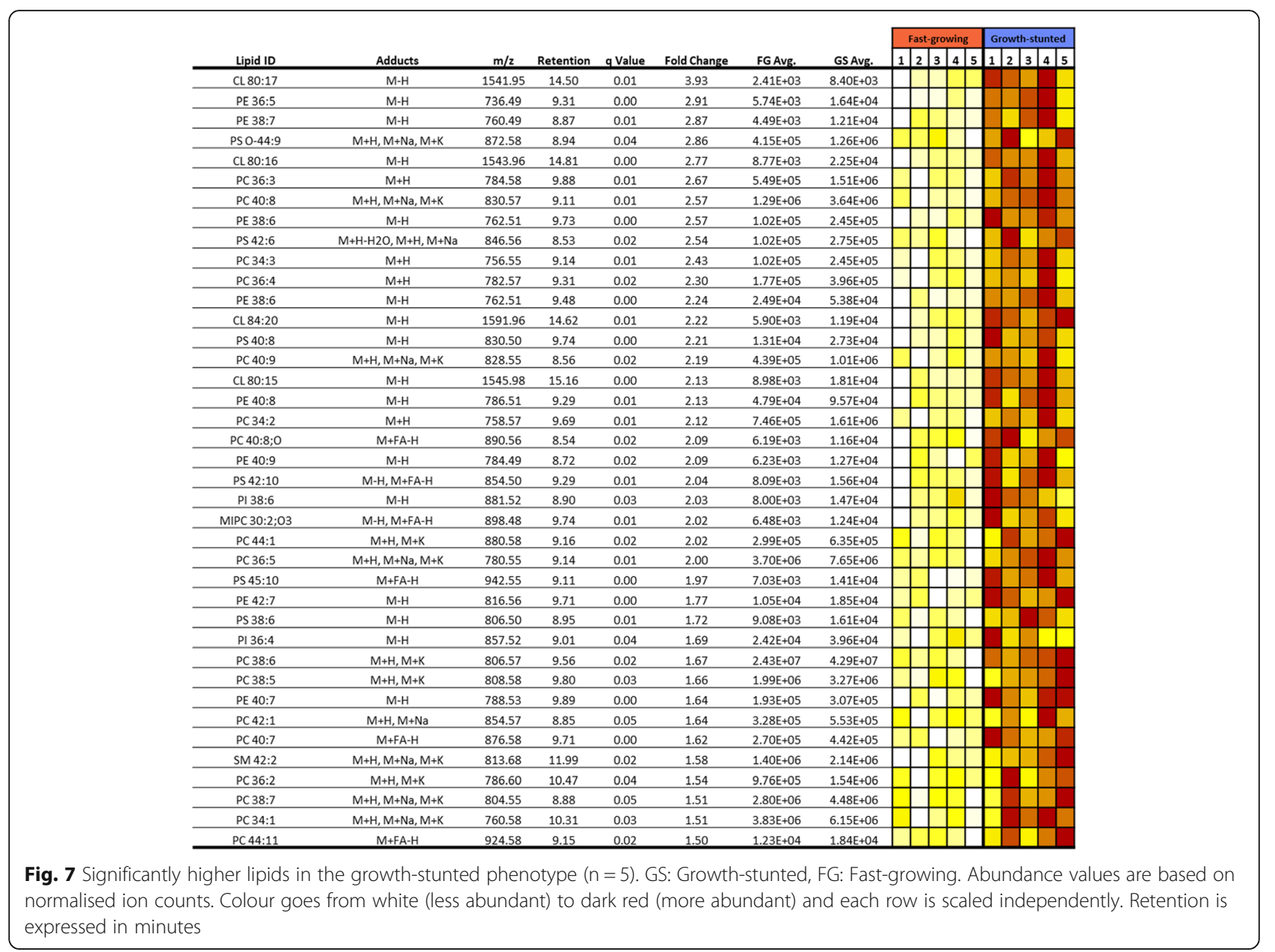

forcefully transferred to seawater. Another hypothesis for the reduction in growth once fish are transferred could be that GS fish become subordinate fish. Other studies have demonstrated how subordinate social status has a detrimental effect on growth, which is accompanied by a metabolic mobilisation of reserves [18, 61]. However, in such cases, metabolic changes have been, at least in part, driven by chronically high levels of plasma cortisol in the subordinate fish $[17,18,62]$. In the present study, plasma cortisol levels were similar between both groups suggesting that this phenotype is unlikely to be triggered by the development of a subordinate social status when animals are transferred at sea. Furthermore, from a metabolic perspective, subordinate fish have been shown to rely on $\beta$-oxidation of circulating free fatty acids rather than on triglycerides for energy [22] a feature not observed in the seawatertransferred GS phenotype.

The liver is a key organ for the accumulation and mobilization of energy reserves [37]. A labelled proteomic approach was used to unravel differences in the liver proteome between FG and GS. From a protein perspective, several proteins from the 19 identified differential proteins consistently pointed towards ER stress in GS livers. The ER is central to the processes of energy production, protein and lipid synthesis and it is closely related to oxidative stress and redox homeostasis [44]. In this study, an upregulation of chaperones known to increase in response to ER stress such as calreticulin and PDI [63, 64] was detected in GS livers. Downregulated differential proteins in the GS phenotype included catalase (I and II), a crucial antioxidant enzyme, the inhibition of which has been reported under ER stress conditions. Other proteins also reported to be closely linked to ER stress and redox homeostasis, such as glycine $\mathrm{N}$-methyltransferase, or involved in lipid and energy homeostasis, such as annexin, SCP-2 and malate dehydrogenase were also differentially expressed in the two phenotypes $[65,66]$. The increase, and more recently the proven relocation of stress induced ER cytosol chaperones to the cell plasma membrane have expanded the understanding of the functional role of these proteins, which can modulate immune responses in response to proteotoxic stress [67]. Within this context, ER stress 
has been shown to induce inflammation. The release of cytokines can be directly induced by ER/unfolded protein response (UPR) pathways or indirectly through the interaction with innate immune cells. In other organisms, the cross-talk of Toll-like receptors and ER/UPR pathways is associated to viral infections due to increased viral protein synthesis and assembly. This hypothesis cannot be discarded, as in the GS phenotype, besides the indication of ER stress, an increase in granzyme $M$ was detected. This protein is a chymotrypsinlike serine protease that is abundantly expressed in innate effector natural killer cells and acts as a first line of defence against virus-infected or transformed tumour cells [68]. With current data, it is not possible to map out if the activation of ER/UPR pathways is a trigger or a consequence of an inflammatory state, a question that has been previously raised [69].

Other proteins upregulated in GS livers included the chaperone HSP90- $\alpha 1$, alpha-2-macroglobulin (broad spectrum protease inhibitor) and other proteins also associated with the ER. These proteins are involved in the translocation of secretory proteins (i.e. translocating chain-associated membrane protein) or involved in providing reducing equivalents to maintain adequate levels of reductive cofactors in the ER (i.e. GDH/6PGL endoplasmic bifunctional protein) [70, 71]. Therefore, our proteomic results in GS point towards ER stress as a key mechanism reflecting a state of functional imbalance.

As already mentioned, the ER is a key organelle of cellular lipid synthesis coordinating the transfer of lipids at the cellular level with ER stress associated with anomalous lipid metabolism [72]. In this respect, ER stressors can disrupt lipid metabolism. Lipidomic data showed important differences in the hepatic lipid composition of the two phenotypes. The biggest differences between FG and GS livers were found in energy reserve species (i.e. TAGs), which were lower in GS fish livers. Other studies have shown how ER stressors such as starvation and nutrient deficiencies can modulate autophagy, which plays a vital role in cell survival under long-term ER stress situations [73]. Autophagy provides cells with energy by mobilising energy stores such as TAGs. This mobilisation of lipid reserves is clearly observed in GS fish livers.

Other lipids which differentiated the two phenotypes were found in the phospholipid fraction. Phospholipids are key structural constituents of cellular membranes and of lipoproteins involved in the transport of dietary lipid from the intestine and liver to the rest of the body $[74,75]$. In general terms, glycerophospholipids were elevated in GS fish livers, mainly PC, PE, PS and CL. Previous studies have reported that changes in PC species associated with dietary vegetable oil intake may cause an abnormal lipid deposition in the liver [76], which has also been linked to reduced growth [77] and suppressed immunity and antioxidant capacity [78]. Perturbations of glycerophospholipids, especially PC and PE levels, can result in lipid bilayer stress, which in turns causes ER stress [79]. Furthermore, being components of membranes, glycerophospholipids are affected by oxidative stress. This is especially the case for CL, due to their almost exclusive location in mitochondrial membranes where the electron-transport chain occurs, and where there is intense ROS production [80]. CL are involved in the biogenesis, dynamics and organization of mitochondrial membranes, controlling their permeability and contributing to the assembly of mitochondrial protein complexes involved in respiration and energy production [81, 82]. These lipids, which were elevated in GS fish livers, can be used as biomarkers for mitochondrial dysfunction [82, 83].

Some interesting associations between the proteomics and lipidomics datasets were also found. For instance, the higher abundance of the differential protein SCP-2 in the FG group is likely related to the higher abundance of TAGs found in this group. SCP-2 is thought to transfer cholesterol and phospholipids from the inner ER membrane to the plasma membrane [84], binding both fatty acids and isoprenoids such as dolichol [85], and facilitating the esterification of cholesterol to cholesterylesters. This putative SCP-2 was more abundant in FG fish, with C20:3 cholesteryl-ester also found to be elevated within the same condition, albeit at low absolute levels. The abundance of TAG in FG fish livers likely results in the formation of lipoproteins within the blood, resulting in the translocation of cholesterol and phospholipid to the plasma membrane, as well as the upregulation of cholesteryl-esters as a means of storage. Also of interest is the decreased abundance, 21-fold, of dolichol in GS fish livers. GS fish were found to have elevated dolichyl-disphophooligosaccharide-protein glycosyltransferase subunit 1 protein, which correlates with the reduction in the dolichol substrate pool. Decrease in dolichol has been proposed as a marker of aging, as well as of calorie restriction. In calorie restricted mice, dolichol was found to decrease in the liver [86], with this trend appearing to be present within the GS fish, this may indicate that at least to some extent, GS are experiencing caloric restriction.

$\mathrm{CL}$ are implicated in the energetic balance $[81,82]$ and ceramides regulate a wide variety of molecular processes $[87,88]$. While they are very different in composition and nature, both lipid classes are prone to peroxidation, which can lead to dysfunctional mitochondria in the case of CL [80], and to the induction of apoptosis for ceramides [87, 89]. In this sense, the differential proteins catalase (I and II) and PDI (I, II, and III) are both involved in cell redox homeostasis. Catalase catalyses the decomposition of hydrogen peroxide to water and 
oxygen and its activity is used as a biomarker of oxidative stress. Therefore, it is a crucial enzyme in protecting the cell from oxidative damage by ROS and has been proposed as a biomarker and potential tool for the treatment of liver diseases like hepatitis and hepatocarcinoma [90]. Moreover, this enzyme may also control bioenergetic metabolism by regulating the activity of the Krebs cycle, respiratory chain, and ATP synthesis [90]. On the other hand, PDI acts as a converging hub for hydrogen peroxide generation pathways, including oxidases and peroxidases [91]. Moreover, it is tightly connected to oxidoreductases, mitochondria, and NADPH oxidases, the three main mechanisms of oxidant generation [91-93]. Therefore, although PDI deficiency results in health conditions [94, 95], it represents a mechanism of oxidative stress regulation. Therefore, these two seemingly opposite differential proteins, in combination with the differences in $\mathrm{CL}$ and ceramide lipid composition, seem to indicate that GS might be under higher levels of oxidative stress. In turn, this could be associated with dysfunctional hepatic cellular membranes and mitochondrial membranes and might explain their physiological challenges. Indeed, hepatic oxidative stress induced by diet $[49,96]$ or chemical exposure has been linked to decreased growth and feed efficiency in fish. Therefore, it is possible that GS fish have different nutritional needs that their current diet is unable to fulfil.

\section{Conclusions}

Results from this study reveal ER stress as a key mechanism underlying stunted growth in seawater transfer in rainbow trout. While the drivers leading to the activation of ER stress are still unknown, proteomic and lipidomic data point towards a nutritional deficiency as an underlying driver of this phenotype. Future efforts should be directed at identifying the genetic traits of GS and re-evaluate feed formulations that can offset the nutritional deficiencies of GS.

\section{Methods}

\section{Fish and rearing conditions}

Post-smolt rainbow trout (O. mykiss) with a weight of $247.9 \pm 2.21 \mathrm{~g}($ mean $\pm \mathrm{SE})$ at seawater transfer $(n=306)$ were used in this experiment. Fish were fed ad libidum using a standard commercial dry diet (Skretting AS) from automatic feeders according to temperature and fish size. Fish were kept indoors in tanks equipped with LED lights in a rainbow trout facility from Lerøy Vest AS (Bjørsvik, Hordaland, Norway). Animals were kept at continuous light, natural temperature, water flow at 0.4 $\mathrm{L} / \mathrm{kg} / \mathrm{min}$ and $\mathrm{O}_{2}$ was above $80 \%$ in the outlet.

The present experiment was carried out on a subset of samples from $n=64(n=32$ GS and $n=32$ FG) tagged (Carlin) fish generated in Morro et al. (2019). GS

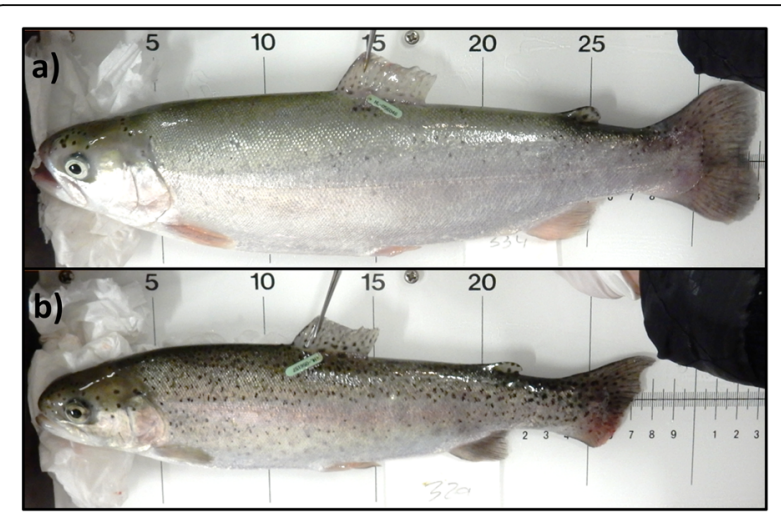

Fig. 8 A representative specimen of the fast-growing (a) and growth-stunted (b) phenotypes in seawater-transferred rainbow trout

presented the lowest Fulton index $\left(<1.25 \mathrm{~g} \mathrm{~cm}^{-3}\right)$ and standard growth rate (SGR) $\left(<0.65 \%\right.$ day $\left.^{-1}\right)$ in the batch, while FG presented the highest Fulton index $(>1.45 \mathrm{~g}$ $\mathrm{cm}^{-3}$ ) and SGR $\left(>0.65 \%\right.$ day $\left.^{-1}\right)$. A representative specimen of each phenotype can be seen in Fig. 8.

\section{Sampling}

Non-lethal sampling for morphometrics and blood took place on the 5th of July. Fish were transferred to seawater on the same day and lethal sampling took place 9 weeks after on the 14th of September.

For the lethal sampling, fish were quickly dip-netted out of the tanks and euthanized by a lethal overdose of isoeugenol (AQUI-S). Weight and total length were recorded. Blood was withdrawn using heparinised syringes and centrifuged at $3500 \times \mathrm{g}$ for $10 \mathrm{~min}$ to obtain plasma, which was frozen at $-80^{\circ} \mathrm{C}$. The first gill arch was dissected out and preserved at $-80^{\circ} \mathrm{C}$ in SEI buffer (Sucrose $250 \mathrm{mM}, \mathrm{Na}_{2}$ EDTA $10 \mathrm{mM}$, Imidazole $50 \mathrm{mM}$ (all Sigma-Aldrich)). Liver samples were either preserved fresh frozen at $-80^{\circ} \mathrm{C}$ (for proteomic and lipidomic analysis) or preserved in RNAlater overnight at $4{ }^{\circ} \mathrm{C}$ and frozen at $-80^{\circ} \mathrm{C}$ according to manufacturer guidelines (for transcription analysis).

\section{Gill $\mathrm{Na}^{+}, \mathrm{K}^{+}$-ATPase (NKA) activity}

NKA activity is a measurement of osmoregulatory capacity in seawater and of the smoltification status. NKA activity was measured in gill tissue collected from 17 randomly selected fish from each group at the end-point sampling in seawater $(n=17)$.

Activity was measured following McCormick [97], which couples the hydrolysis of ATP to the enzymatic production of $\mathrm{NAD}^{+}$through the involvement of the enzymes pyruvate kinase and lactate dehydrogenase, and uses the NKA inhibitor ouabain to trace the baseline. Kinetic assay readings were carried out at $340 \mathrm{~nm}$ for 10 
min $\left(60\right.$ cycles) at $25^{\circ} \mathrm{C}$ in a Sunrise-basic (Tecan) spectrophotometer. Total amount of protein in the homogenate was analysed using a bicinchoninic acid (BCA) assay run in triplicate. NKA values were determined as the ouabain sensitive fraction of the ATP hydrolysis, expressed as $\mu$ mol ADP mg protein ${ }^{-1} h^{-1}$.

\section{Time-resolved fluoroimmunoassay for plasma IGF-I}

Circulating IGF-I levels were measured in plasma collected from 8 randomly selected fish from each group $(n=8)$. Repeated measurements took place on the same fish before seawater transfer and at the end-point sampling in seawater.

Time-resolved competitive fluoroimmunoassay (TRFIA) was used to measure plasma IGF-I concentration [98]. Prior to the assay, plasma IGF-I was dissociated from the binding protein with acid-ethanol [99]. Specific details of the method are explained in Morro et al. [10].

\section{Plasma cortisol}

Plasma cortisol levels were measured in plasma collected from randomly selected fish from each group, $n=15$ in freshwater and $n=30$ in seawater. Plasma cortisol levels of all fish sampled in freshwater (15) were measured again in seawater.

Plasma cortisol was measured using a custom enzymelinked immunoassay (ELISA). Specific details of the method are explained in Bos et al. [100], with a volume of plasma or controls of $10 \mu \mathrm{l}$ in this case.

\section{Real-time polymerase chain reaction (RT-PCR)}

RT-PCR analysis was performed on liver tissue collected from 8 randomly selected fish from each group at the end-point sampling in seawater $(n=8)$.

FG and GS individuals were analysed for liver igfl, igfbp $1 b, g h r 1$ and ctsl mRNA abundance as previously described in Morro et al. [10]. Briefly, 20-25 mg of liver tissue was homogenized in RLT buffer (Qiagen). Total RNA isolation was carried out using the Qia symphony RNA kit in the QIAsymphony SP automatic system following manufacturer instructions (Qiagen). Complementary DNA was reversely transcribed using $1.4 \mu \mathrm{g}$ of total RNA using oligo (dT20) primer and the Superscript III kit (Thermo Fisher Scientific). Pipetting for both cDNA synthesis and RT-PCR was carried out using a MicrolabSTARlet Liquid Handling Workstation (Hamilton Robotics). RT-PCR was performed in a CFX96 Real-Time PCR platform (Bio-Rad) using the following PCR conditions: $3 \mathrm{~min}$ at $95^{\circ} \mathrm{C}, 34$ cycles of $15 \mathrm{~s}$ at $95^{\circ} \mathrm{C}$ and $1 \mathrm{~min}$ at $60^{\circ} \mathrm{C}$ and a melting curve step at the end $\left(10 \mathrm{~s}\right.$ at $95^{\circ} \mathrm{C}, 5 \mathrm{~s}$ at $65-95^{\circ} \mathrm{C}$ with increments of $0.5^{\circ} \mathrm{C}$ and $5 \mathrm{~s}$ at $95^{\circ} \mathrm{C}$ ). Samples were run in $25 \mu \mathrm{l}$ duplicates using iTaq universal SYBR green supermix (BioRad), $0.20 \mu \mathrm{M}$ of each primer and $5 \mu$ l of 1:30 diluted cDNA. Samples with a coefficient of variation between duplicates above $1.25 \%$ were run again. The relative transcription levels of the genes were normalized following the efficiency corrected method [101] using ef1 $\alpha$ as an endogenous reference gene [102]. Primers used in this study are summarized in Table 1.

\section{Liver proteome analysis \\ Samples}

To compare the liver proteome of the FG and GS phenotypes, livers of $5 \mathrm{FG}$ and 5 GS individuals were selected. The criteria for GS were low weight $(<285 \mathrm{~g})$, Fulton index $\left(<1.21 \mathrm{~g} \mathrm{~cm}^{-3}\right)$ and SGR $\left(<0.5 \% \mathrm{day}^{-1}\right)$ while for FG it was high weight $(>460 \mathrm{~g})$, Fulton index $\left(>1.50 \mathrm{~g} \mathrm{~cm}^{-3}\right)$ and growth $\left(>0.9 \%\right.$ day $\left.^{-1}\right)$ (Table 2).

\section{Liver sample preparation}

Homogenization of $50 \mathrm{mg}$ of liver was done in $1 \mathrm{ml}$ of $0.1 \mathrm{M}$ Tris- $\mathrm{HCl} \mathrm{pH} 7.6$ supplemented with $1 \%$ protease inhibitor cocktail (Roche) using a pestle motor mixer. Sodium dodecyl sulphate and dithiothreitol were added to the homogenates to a final concentration of $4 \%$ and $0.1 \mathrm{M}$, respectively. The samples were then incubated at $95^{\circ} \mathrm{C}$ for $5 \mathrm{~min}$ and cleared by centrifugation at 16,000 $\mathrm{xg}$ for $10 \mathrm{~min}$ at room temperature.

Table 1 Primers used for RT-PCR analysis. Accession numbers of the gene sequences were obtained from GeneBank

\begin{tabular}{|c|c|c|c|}
\hline Gene name & Primer sequence $\left(5^{\prime}>3^{\prime}\right)$ & Accession number & Reference \\
\hline$\overline{\lg f 1}$ & $\begin{array}{l}\text { TGCGGAGAGAGAGGCTITA } \\
\text { AGCACTCGTCCACAATACCA }\end{array}$ & M81904 & [103] \\
\hline igfbp 1b & $\begin{array}{l}\text { AGTTCACCAACTTCTACCTACC } \\
\text { GACGACTCACACTGCTTGGC }\end{array}$ & AF403539 & [104] \\
\hline ghr1 & $\begin{array}{l}\text { CGTCCTCATCCTTCCAGTTTTA } \\
\text { GTTCTGTGAGGTTCTGGAAAAC }\end{array}$ & AF403539 & [104] \\
\hline ctsl & $\begin{array}{l}\text { CAACTACCTGCAGGCACCTA } \\
\text { ACATGATCCCTGGTCCTTGAC }\end{array}$ & AF358668 & [103] \\
\hline efal & $\begin{array}{l}\text { CCCCTCCAGGATGTCTACAAA } \\
\text { CACACGGCCCACGGGTACT }\end{array}$ & AF498320 & [105] \\
\hline
\end{tabular}


Table 2 Growth attributes of fish included in the FG and GS phenotypes. Samples were analysed by LC-MS/MS (proteomics) and LC-MS (lipidomics)

\begin{tabular}{lllll}
\hline Sample & Length (cm) & Weight (g) & Fulton index & SGR \\
\hline FG & $31.7 \pm 0.28^{\mathrm{a}}$ & $494.3 \pm 9.97^{\mathrm{a}}$ & $1.6 \pm 0.03^{\mathrm{a}}$ & $1.0 \pm 0.08^{\mathrm{a}}$ \\
GS & $26.8 \pm 0.70^{\mathrm{b}}$ & $230.2 \pm 18.56^{\mathrm{b}}$ & $1.2 \pm 0.01^{\mathrm{b}}$ & $0.1 \pm 0.14^{\mathrm{b}}$ \\
\hline
\end{tabular}

Length, weight and Fulton index correspond to end-point sampling measurements. Fulton index is measured in $\mathrm{g} \mathrm{cm}^{-3}$. SGR is measured in weight gain (\%) day ${ }^{-1}$.

\section{TMT labelling}

After measuring protein concentration by BCA (Interchim Uptima) equal amounts of protein $(100 \mu \mathrm{g})$ were reduced, alkylated, precipitated, trypsin digested and TMT labelled following manufacturer instructions (TMT10plex $^{\text {TM }}$ Isobaric Label Reagent Set, ThermoFisher Scientific). Multiplexed peptide samples were cleaned-up using Hypersep SpinTip (ThermoFisher Scientific), according to manufacturer instructions. Finally, samples were dried using a vacuum drier (Savant DNA SpeedVac 110, Thermo Scientific).

\section{LC MS/MS analysis of TMT}

Samples were analysed with an LTQ-Orbitrap XL LC MSn mass spectrometer (Thermo Fisher Scientific) equipped with a nanospray source and coupled to an Ultra High Pressure Liquid Chromatographer system (Waters nanoAcquity). Initially, $5 \mu \mathrm{L}$ of sample resuspended in ultrapure water was loaded, desalted and concentrated in a BEH C18 trapping columns (Waters) with the instrument operated in positive ion mode. The peptides were then separated on a BEH C18 nanocolumn $(1.7 \mu \mathrm{m}, 75 \mu \mathrm{m} \times 250 \mathrm{~mm}$, Waters $)$ at a flow rate of 300 $\mathrm{nL} / \mathrm{min}$ using an $\mathrm{ACN} /$ water gradient; $1 \% \mathrm{ACN}$ for 1 min, followed by $0-62.5 \%$ ACN over $21 \mathrm{~min}, 62.5-85 \%$ $\mathrm{ACN}$ for $1.5 \mathrm{~min}, 85 \% \mathrm{ACN}$ for $2 \mathrm{~min}$ and $1 \% \mathrm{ACN}$ for $15 \mathrm{~min}$.

MS spectra were collected using data-dependent acquisition in the $\mathrm{m} / \mathrm{z}$ range $400-2000$ using a precursor ion resolution of 30,000 , following which individual precursor ions (top 5) were automatically fragmented using collision induced dissociation with a relative collision energy of $35 \%$. Dynamic exclusion was enabled with a repeat count of 2 , repeat duration of $30 \mathrm{~s}$ and exclusion duration of $180 \mathrm{~s}$.

\section{LC MS/MS data analysis and sequence annotation for TMT}

MS data was analysed using Proteome Discoverer (ThermoFisher Scientific). Peak integration allowed for a window tolerance of $20 \mathrm{ppm}$ using the 'most confident centroid' method. Peptide quantification was based on TMT label abundance. Only unique peptides were used for protein quantification (i.e. peptides that could be exclusively matched to a single protein in the database).
Data across samples was normalized based on protein median. Only high-confidence peptides were used for quantification. Protein abundance was further normalized by dividing it in each sample by the total abundance for that protein (sum of all 10 samples). A multiple ttest followed by FDR 5\% was used to compare the abundance of each detected protein in both conditions.

Peptide sequences were annotated by database search against the rainbow trout SwissProt database, which was downloaded from MASCOT and loaded into Proteome Discoverer. The initial search parameters allowed for a single trypsin missed cleavage, carbamidomethyl modification of cysteine residues, oxidation of methionine, acetylation of $\mathrm{N}$-terminal peptides, a precursor mass tolerance of $10 \mathrm{ppm}$, a fragment mass tolerance of $\pm 0.5 \mathrm{Da}$, and an FDR of 1\%. Any proteins named 'uncharacterised' in the rainbow trout protein database were further searched by sequence homology against the Atlantic salmon (Salmo salar), zebrafish (Danio rerio), and human (Homo sapiens) SwissProt databases, in this order. Only homologies of E-value higher than 0.01 were accepted as valid.

Data was tested for normal distribution and homogeneity of variance assumptions using the Shapiro and Bartlett tests, respectively. Next, multiple t-test analysis and $5 \%$ FDR correction were used.

\section{Liver lipidome analysis Individual samples}

The same liver samples from FG and GS ( $n=5$ /group) described in the liver proteome section were used for lipidomic analysis (Table 2).

\section{Lipid extraction}

Lipid extraction was carried out following the Folch method [106, 107]. Briefly, $25 \mathrm{mg}$ of liver sample were homogenized in $10 \mathrm{ml}$ of chloroform/methanol (2:1), incubated on ice for $1 \mathrm{~h}$, with $2.5 \mathrm{ml}$ of $0.88 \% \mathrm{KCl}$ added, vortexed, incubated on ice for $5 \mathrm{~min}$ and centrifuged at $400 \mathrm{xg}$ for 5 mins. Afterwards, the top layer was removed by aspiration and the lower layer was filtered through paper filters (No.1, Whatman). Solvent was evaporated under a stream of oxygen-free nitrogen and desiccated in vacuo overnight. Samples were stored under argon at $-20^{\circ} \mathrm{C}$.

\section{LC MS/MS analysis of lipids}

Lipids were analysed by LC-MS using a Thermo Orbitrap Exactive MS (Thermo Scientific), equipped with a heated electrospray ionization probe and coupled to a Thermo Accela1250U HPLC system. All samples were analysed in both positive and negative ionization modes over the $\mathrm{m} / \mathrm{z}$ range 200-2000. The samples were injected into a Thermo Hypersil Gold C18 column (2.1 
$\mathrm{mm} \times 100 \mathrm{~mm}, 1.9 \mathrm{~mm}$ ). Mobile phase A consisted of water containing $10 \mathrm{mM}$ ammonium formate and $0.1 \%$ (v/v) formic acid. Mobile phase B consisted of 9:1 isopropanol/ACN containing $10 \mathrm{mM}$ ammonium formate and $0.1 \%(\mathrm{v} / \mathrm{v})$ formic acid. All solvents were LC-MS grade (Fisher Scientific). The initial conditions for analysis were $65 \% \mathrm{~A} / 35 \% \mathrm{~B}$. The percentage of mobile phase B was increased to $100 \%$ over $10 \mathrm{~min}$ and held for 7 mins before re-equilibration with the starting conditions for 4 mins.

\section{LC MS/MS data analysis and lipid identification}

Raw LC-MS data was processed with Progenesis QI v2.4 software (Non-linear Dynamics). Relative fold quantification was performed by the software using all ion normalization, followed by data filtering based on the ANOVA score $(<0.05)$, fold change $(>1.5)$ and ANOVA FDR $(<0.05)$. This was performed for data acquired in both positive and negative ionization modes. Retention and mass aligned feature data were exported for multivariate analysis (Simca-P v12.0), with OPLS-DA with parametric scaling used for data analysis [108]. An Splot was used to identify features of interest - features with a w (1) score higher than $+/-0.04$ and a $\mathrm{p}$ (corr) score greater than $+/-0.6$ selected. These features were then identified using both the Lipid Maps and Lipidblast databases.

\section{General data analysis and representation}

Figures were plotted using $\mathrm{R}$ statistical software and $\mathrm{R}$ package ggplot2 [109].

Differential proteins and differential lipids (both qvalue $<0.05$ ) were plotted in heatmap form showing individual sample abundance scaled by protein (i.e. by row) for liver proteins.

Unpaired t-test was used to test for differences in morphometric data, liver protein and lipid percentage, NKA activity, IGF-I abundance, cortisol abundance, and gene transcription among FG and GS groups. Data was transformed by either natural logarithm or square root to satisfy the normal distribution and homogeneity of variance assumptions, tested with the Shapiro and Bartlett tests, respectively. Similarly, paired t-test was used to test for differences between freshwater and seawater IGF-I abundance.

\section{Abbreviations}

AWERB: Animal Welfare and Ethical Review Body; BCA: Bicinchonic acid assay; CL: Cardiolipins; CTSL: Cathepsin L; ER: Endoplasmic reticulum; ELISA: Enzyme-linked immunoassay; FG: Fast-growing; GHR1: Growth hormone receptor 1; GS: Growth-stunted; IGF-I: Insulin-like growth factor 1; IGFBP1: Insulin-like growth factor binding protein 1; LC-MS: Liquid chromatography - mass spectrometry; LC-MS/MS: Liquid chromatography tandem mass spectrometry; NKA: $\mathrm{Na}^{+}, \mathrm{K}^{+}$-ATPase; NARA: Norwegian Animal Research Authority; OPLS-DA: Orthogonal partial Least-squares discriminant analysis; PC: Phosphatidylcholine; PE: Phosphatidylethanolamine; PI: Phosphatidylinositol; PS: Phostidylserine; PDI: Protein disulphide
}

isomerases; ROS: Reactive oxygen species; RT-PCR: Real-time polymerase chain reaction; SGR: Standard growth rate; SCP-2: Sterol carrier protein 2; TRFIA: Time-resolved competitive fluoroimmunoassay; TAGs: Triacylglycerides; UPR: Unfolded protein response

\section{Supplementary Information}

The online version contains supplementary material available at https://doi. org/10.1186/s12864-021-08153-5.

Additional File 1. TMT proteome dataset output from Proteome discoverer on FG and GS fish liver samples.

Additional File 2. Lipidomic dataset containing lipid features found to distinguish FG and GS fish. Compounds found to significantly drive the separation were identified using OPLS-DA analysis (w [1] score > +/- 0.04 and a $p$ (corr) [1] score $>+/-0.6$ ).

Additional File 3. Suppl. Fig. 1. S-plot of lipidomics data between FG and GS phenotypes. The $\mathrm{x}$-axis represents the contribution value that separates the experimental groups ( $w$ [1]) while the $y$-axis represents the reliability (pcorr [1]). Each point represents a single $\mathrm{m} / \mathrm{z}$ feature data pair. The further the data point is from the origin the greater the contribution is from this feature to differentiate among the two groups. Feature information and numerical data available in Additional File 2

\section{Acknowledgements}

Not applicable.

\section{Authors' contributions}

BM performed analysis and drafted the manuscript. RB performed data analysis and wrote sections on the manuscript; PB, MKD, PW, MS and MG performed or contributed to the acquisition of data. SM, SOH and HS conceived and designed the experiment. AA performed analysis, drafted the manuscript with BM and designed the work included in this manuscript. All authors read and provided feedback to the manuscript.

\section{Funding}

This work received funding from the MASTS pooling initiative (The Marine Alliance for Science and Technology for Scotland; grant SASG9 and SG506) and their support is gratefully acknowledged. MASTS is funded by the Scottish Funding Council (grant reference HR09011) and contributing institutions. We also gratefully acknowledge the support of UHI Aquaculture Innovation Fund and European Regional Development Fund, Scottish Funding Council and Highlands and Islands Enterprise (UHI SDB Plan -ERDF 2 (H\&l/ERDF/2008/1/2/0090)).

This work was supported by the Regionale Foskningsfond Vestlandet project: Utvikling av. en sesonguavhengig protokoll for intensive produksjon av. regnbueørret (O. mykiss). (Development of a season independent protocol for the intensive production of rainbow trout (O.mykiss)) (RFFVest project 248020), the CtrIAQUA SFI, Centre for Closed-Cotainment Aquaculture programme (SFI project 237856), and by Japan Society for the Promotion of Science Bilateral Joint Research Project (open partnership with Norway).

\section{Availability of data and materials}

All data generated or analysed during this study are included in this published article [and its supplementary information files]. The mass spectrometry proteomics data generated during the current study has been deposited to the ProteomeXchange Consortium via the PRIDE partner repository with the dataset identifier PXD026897.

\section{Declarations}

\section{Ethics approval and consent to participate}

This study was carried out in compliance with the ARRIVE guidelines. Experimental work was ethically reviewed, approved and registered by the Norwegian Animal Research Authority (NARA), the Animal Welfare and Ethical Review Body (AWERB 088, University of Stirling, UK) and by the University of Highlands and Islands Ethical committee. All methods were carried out in accordance with relevant guidance and regulations. 


\section{Consent for publication}

Not applicable.

\section{Competing interests}

The authors declare that they have no competing interests.

\section{Author details}

${ }^{1}$ Institute of Aquaculture, University of Stirling, Stirling, UK. ${ }^{2}$ NORCE AS, Bergen, Norway. ${ }^{3}$ Department of Biological Sciences, University of Bergen, Bergen, Norway. ${ }^{4}$ Institute of Health Research and Innovation, Centre for Health Science, University of the Highlands and Islands, Scotland, UK. ${ }^{5}$ Institute of Infection, Immunity and Inflammation, University of Glasgow, Scotland, UK. ${ }^{6}$ Faculty of Fisheries Sciences, Hokkaido University, Sapporo, Japan. 7 Department of Animal Ecology and Physiology, Radboud University, Institute of Water and Wetland Research, Nijmegen, The Netherlands. ${ }^{8}$ Lerøy Seafood Group ASA, Bergen, Norway.

Received: 2 June 2021 Accepted: 1 November 2021 Published online: 16 November 2021

\section{References}

1. Gjedrem T, Robinson N, Rye M. The importance of selective breeding in aquaculture to meet future demands for animal protein: a review. Aquaculture. 2012;350(117):129-9. https://doi.org/10.1016/j.aquaculture.2012. 04.008 .

2. Janssen $K$, Chavanne $H$, Berentsen $P$, Komen $H$. Impact of selective breeding on European aquaculture. Aquaculture. 2017:472:8-16. https://doi.org/10.101 6/j.aquaculture.2016.03.012.

3. Sartelet A, Druet T, Michaux C, Fasquelle C, Géron S, Tamma N, et al. A splice site variant in the bovine RNF11 gene compromises growth and regulation of the inflammatory response. PLoS Genet. 2012;8(3):e1002581. https://doi.org/10.1371/journal.pgen.1002581.

4. Christie MR, Marine ML, Blouin MS. Who are the missing parents? Grandparentage analysis identifies multiple sources of gene flow into a wild population. Mol Ecol. 2011;20(6):1263-76. https://doi.org/10.1111/j.1365-294 X.2010.04994.X.

5. Kendall NW, McMillan JR, Sloat MR, Buehrens TW, Quinn TP, Pess GR, et al. Anadromy and residency in steelhead and rainbow trout (Oncorhynchus mykiss): a review of the processes and patterns. Can J Fish Aquat Sci. 2015; 72(3):319-42. https://doi.org/10.1139/cjfas-2014-0192.

6. Sharpe CS, Beckman BR, Cooper KA, Hulett PL. Growth modulation during juvenile rearing can reduce rates of residualism in the progeny of wild steelhead broodstock. N Am J Fish Manage. 2007;27(4):1355-68. https://doi. org/10.1577/M05-220.1.

7. Sloat MR, Reeves GH. Individual condition, standard metabolic rate, and rearing temperature influence steelhead and rainbow trout (Oncorhynchus mykiss) life histories. Can J Fish Aquat Sci. 2014;71(4):491-501. https://doi. org/10.1139/cjfas-2013-0366.

8. Hayes SA, Hanson CV, Pearse DE, Bond MH, Garza JC, MacFarlane RB. Should I stay or should I go? The influence of genetic origin on emigration behavior and physiology of resident and anadromous juvenile Oncorhynchus mykiss. N Am J Fish Manage. 2012;32(4):772-80. https://doi. org/10.1080/02755947.2012.686953.

9. FAO: The State of World Fisheries and Aquaculture 2020. Sustainability in action. FAO 2020.

10. Morro B, Balseiro P, Albalat A, Pedrosa C, Mackenzie S, Nakamura S, et al. Effects of different photoperiod regimes on the smoltification and seawater adaptation of seawater-farmed rainbow trout (Oncorhynchus mykiss): Insights from $\mathrm{Na}, \mathrm{K}$-ATPase activity and transcription of osmoregulation and growth regulation genes. Aquaculture. 2019;507:282-92. https://doi. org/10.1016/j.aquaculture.2019.04.039.

11. Morro B, Balseiro Vigo P, Albalat A, Mackenzie S, Pedrosa C, Nilsen TO, et al. Effects of temperature and photoperiod on rainbow trout (Oncorhynchus mykiss) smoltification and haematopoiesis. Aquaculture. 2019;519:734711. https://doi.org/10.1016/j.aquaculture.2019.734711.

12. Roiha IS, Maage A, Levsen A. Farmed rainbow trout (Oncorhynchus mykiss) in Norway are at low risk of carrying anisakid nematodes. J Appl Aquac. 2020;33(4):1-12. https://doi.org/10.1080/10454438.2020.1785368.

13. Skov J, Mehrdana F, Marana MH, Bahlool QZM, Jaafar RM, Sindberg D, et al. Parasite infections of rainbow trout (Oncorhynchus mykiss) from Danish mariculture. Aquaculture. 2014;434:486-92. https://doi.org/10.1016/j.aqua culture.2014.08.041.

14. Sloman K, Gilmour K, Taylor A, Metcalfe N. Physiological effects of dominance hierarchies within groups of brown trout, Salmo trutta, held under simulated natural conditions. Fish Physiol Biochem. 2000;22(1):11-20. https://doi.org/10.1023/A:1007837400713.

15. Sloman K, Motherwell G, O'connor K, Taylor A. The effect of social stress on the standard metabolic rate (SMR) of brown trout. Salmo trutta Fish Physiol Biochem. 2000;23(1):49-53. https://doi.org/10.1023/A:1007855100185.

16. Vindas MA, Johansen IB, Folkedal O, Höglund E, Gorissen M, Flik G, et al. Brain serotonergic activation in growth-stunted farmed salmon: adaption versus pathology. R Soc Open Sci. 2016;3(5):160030. https://doi.org/10.1098/ rsos. 160030

17. Gilmour KM, DiBattista JD, Thomas JB. Physiological causes and consequences of social status in salmonid fish. Integr Comp Biol. 2005;45(2): 263-73. https://doi.org/10.1093/icb/45.2.263.

18. DiBattista JD, Levesque HM, Moon TW, Gilmour KM. Growth depression in socially subordinate rainbow trout Oncorhynchus mykiss: more than a fasting effect. Physiol Biochem Zool. 2006;79(4):675-87. https://doi.org/10.1086/504612

19. Abbott JC, Dill LM. The relative growth of dominant and subordinate juvenile steelhead trout (Salmo gairdneri) fed equal rations. Behaviour. 1989; 108(1-2):104-13. https://doi.org/10.1163/156853989X00079.

20. Sloman KA, Metcalfe NB, Taylor AC, Gilmour KM. Plasma cortisol concentrations before and after social stress in rainbow trout and brown trout. Physiol Biochem Zool. 2001;74(3):383-9. https://doi.org/10.1086/320426.

21. Damsgård B, Evensen TH, Øverli $\varnothing$, Gorissen M, Ebbesson LO, Rey S, et al. Proactive avoidance behaviour and pace-of-life syndrome in Atlantic salmon. R Soc Open Sci. 2019;6(3):181859. https://doi.org/10.1098/rsos.181 859.

22. Kostyniuk DJ, Culbert BM, Mennigen JA, Gilmour KM. Social status affects lipid metabolism in rainbow trout, Oncorhynchus mykiss. Am J Physiol Regul Integr Comp Physiol. 2018;315(2):R241-55. https://doi.org/10.1152/ajpregu. 00402.2017.

23. Ejike C, Schreck CB. Stress and social hierarchy rank in coho salmon. Trans Am Fish Soc. 1980;109(4):423-6. https://doi.org/10.1577/1548-8659(1980)1 09<423:SASHRI >2.0.CO;2

24. Sloman KA, Taylor AC, Metcalfe NB, Gilmour KM. Effects of an environmental perturbation on the social behaviour and physiological function of brown trout. Anim Behav. 2001;61(2):325-33. https://doi.org/10.1006/anbe.2000.1 567.

25. Gilmour KM, Kirkpatrick S, Massarsky A, Pearce B, Saliba S, Stephany C, et al. The influence of social status on hepatic glucose metabolism in rainbow trout Oncorhynchus mykiss. Physiol Biochem Zool. 2012;85(4):309-20. https:// doi.org/10.1086/666497.

26. Elofsson UO, Mayer I, Damsgård B, Winberg S. Inter-male competition in sexually mature arctic charr: effects on brain monoamines, endocrine stress responses, sex hormone levels, and behavior. Gen Comp Endocrinol. 2000; 118(3):450-60. https://doi.org/10.1006/gcen.2000.7487.

27. Peters G, Faisal M, Lang T, Ahmed I. Stress caused by social interaction and its effect on susceptibility to Aeromonas hydrophila infection in rainbow trout Salmo gairdneri. Dis Aquat Org. 1988;4(2):83-9. https://doi.org/10.3354/ dao004083.

28. Karczewski KJ, Snyder MP. Integrative omics for health and disease. Nat Rev Genet. 2018;19(5):299-310. https://doi.org/10.1038/nrg.2018.4.

29. de Magalhães R, Ferreira CS, Cerqueira MAC, Schrama D, Moreira MJV Boonanuntanasarn $\mathrm{S}$, et al. A proteomics and other omics approach in the context of farmed fish welfare and biomarker discovery. Rev Aquac. 2020; 12(1):122-44. https://doi.org/10.1111/raq.12308.

30. Beale DJ, Karpe AV, Ahmed W. Beyond metabolomics: a review of multiomics-based approaches. In: Beale D, Kouremenos K, Palombo E, editors. Microbial Metabolomics. Springer: Cham; 2016. p. 289-312. https://doi.org/1 0.1007/978-3-319-46326-1_10.

31. Jové M, Naudí A, Ramírez-Núñez O, Portero-Otín M, Selman C, Withers DJ, et al. Caloric restriction reveals a metabolomic and lipidomic signature in liver of male mice. Aging Cell. 2014;13(5):828-37. https://doi.org/10.1111/a cel.12241.

32. Martin SAM, Cash P, Blaney S, Houlihan D. Proteome analysis of rainbow trout (Oncorhynchus mykiss) liver proteins during short term starvation. Fish Physiol Biochem. 2001;24(3):259-70. https://doi.org/10.1023/A:1014015530045.

33. Skorve J, Hilvo M, Vihervaara T, Burri L, Bohov P, Tillander V, et al. Fish oil and krill oil differentially modify the liver and brain lipidome when fed to 
mice. Lipids Health Dis. 2015;14(1):1-12. https://doi.org/10.1186/s12944-0150086-2.

34. Wu Y, Tang J, Zhou C, Zhao L, Chen J, Zeng L, et al. Quantitative proteomics analysis of the liver reveals immune regulation and lipid metabolism dysregulation in a mouse model of depression. Behav Brain Res. 2016;311:330-9. https://doi.org/10.1016/j.bbr.2016.05.057.

35. Lee J, Ji S, Kim B, Yi S, Shin K, Cho J, et al. Exploration of biomarkers for amoxicillin/clavulanate-induced liver injury: multi-omics approaches. Clin Transl Sci. 2017;10(3):163-71. https://doi.org/10.1111/cts.12425.

36. Martel C, Degli Esposti D, Bouchet A, Brenner C, Lemoine A. Non-alcoholic steatohepatitis: new insights from OMICS studies. Curr Pharm Biotechnol. 2012;13(5):726-35. https://doi.org/10.2174/138920112799857558.

37. Burra P. Liver abnormalities and endocrine diseases. Best Pract Res Clin Gastroenterol. 2013;27(4):553-63. https://doi.org/10.1016/j.bpg.2013.06.014.

38. Brown B, Mauldin GE, Armstrong J, Moroff SD, Mauldin GN. Metabolic and hormonal alterations in cats with hepatic lipidosis. J Vet Intern Med. 2000; 4(1):20-6. https://doi.org/10.1111/j.1939-1676.2000.tb01494.x.

39. Mogg TD, Palmer JE. Hyperlipidemia, hyperlipemia, and hepatic lipidosis in American miniature horses: 23 cases (1990-1994). J Am Vet Med Assoc. 1995;207(5):604-7.

40. Gessner DK, Schlegel G, Ringseis R, Schwarz FJ, Eder K. Up-regulation of endoplasmic reticulum stress induced genes of the unfolded protein response in the liver of periparturient dairy cows. BMC Vet Res. 2014;10(1): 1-9. https://doi.org/10.1186/1746-6148-10-46.

41. Zhu Y, Guan Y, Loor JJ, Sha X, Coleman DN, Zhang C, et al. Fatty acidinduced endoplasmic reticulum stress promoted lipid accumulation in calf hepatocytes, and endoplasmic reticulum stress existed in the liver of severe fatty liver cows. J Dairy Sci. 2019;102(8):7359-70. https://doi.org/10.3168/ jds.2018-16015.

42. El-Zayadi AR. Hepatic steatosis: a benign disease or a silent killer. World J Gastroenterol. 2008;14(26):4120-6. https://doi.org/10.3748/wjg.14.4120.

43. Marcu MG, Doyle M, Bertolotti A, Ron D, Hendershot L, Neckers L. Heat shock protein 90 modulates the unfolded protein response by stabilizing IRE1a. Mol Cell Biol. 2002;22(24):8506-13. https://doi.org/10.1128/MCB.22.24. 8506-8513.2002.

44. Erlandsson L, Ducat A, Castille J, Zia I, Kalapotharakos G, Hedström E, et al. Alpha-1 microglobulin as a potential therapeutic candidate for treatment of hypertension and oxidative stress in the STOX 1 preeclampsia mouse model. Sci Rep. 2019;9(1):1-13. https://doi.org/10.1038/s41598-019-44639-9.

45. Liao $\mathrm{Y}, \mathrm{Chen} \mathrm{T}$, Lee $\mathrm{T}$, Wang $\mathrm{H}$, Wang $\mathrm{C}$, Liao L, et al. Glycine Nmethyltransferase deficiency affects Niemann-pick type C2 protein stability and regulates hepatic cholesterol homeostasis. Mol Med. 2012;18(3):412-22. https://doi.org/10.2119/molmed.2011.00258.

46. Hwang I, Uddin MJ, Pak ES, Kang H, Jin E, Jo S, et al. The impaired redox balance in peroxisomes of catalase knockout mice accelerates nonalcoholic fatty liver disease through endoplasmic reticulum stress. Free Radic Biol Med. 2020;148:22-32. https://doi.org/10.1016/j.freera dbiomed.2019.12.025.

47. Esquivel IC, Perez PC, Gonzalez LT, Muñoz Espinosa LE. Acute phase markers in obese children and adolescents with metabolic disorders. Arch Argent Pediatr. 2018;116(4):275-9. https://doi.org/10.5546/aap.2018.eng.275.

48. Barel M, Harduin-Lepers A, Portier L, Slomianny M, Charbit A. Host glycosylation pathways and the unfolded protein response contribute to the infection by Francisella. Cell Microbiol. 2016;18(12):1763-81. https://doi. org/10.1111/cmi.12614

49. Azaza MS, Khiari N, Dhraief MN, Aloui N, Kraïem MM, Elfeki A. Growth performance, oxidative stress indices and hepatic carbohydrate metabolic enzymes activities of juvenile Nile tilapia, Oreochromis niloticus L., in response to dietary starch to protein ratios. Aquac Res. 2015;46(1):14-27. https://doi.org/10.1111/are.12153.

50. Yuan S, Chen D, Zhang K, Yu B. Effects of oxidative stress on growth performance, nutrient digestibilities and activities of antioxidative enzymes of weanling pigs. Asian Australas J Anim Sci. 2007;20(10):1600-5. https://doi. org/10.5713/ajas.2007.1600.

51. Neto RVR, Yoshida GM, Lhorente JP, Yáñez JM. Genome-wide association analysis for body weight identifies candidate genes related to development and metabolism in rainbow trout (Oncorhynchus mykiss). Mol Gen Genomics. 2019;294(3):563-71. https://doi.org/10.1007/s00438-018-1518-2.

52. Ali A, Al-Tobasei R, Lourenco D, Leeds T, Kenney B, Salem M. Genome-wide identification of loci associated with growth in rainbow trout. BMC Genomics. 2020;21(1):1-16. https://doi.org/10.1186/s12864-020-6617-x.
53. Picha ME, Turano MJ, Beckman BR, Borski RJ. Endocrine biomarkers of growth and applications to aquaculture: a minireview of growth hormone, insulin-like growth factor (IGF)-I, and IGF-binding proteins as potential growth indicators in fish. N Am J Aquacult. 2008;70(2):196-211. https://doi. org/10.1577/A07-038.1.

54. Wood AW, Duan G, Bern HA. Insulin-like growth factor signaling in fish. Int Rev Cytol. 2005;243(1):215-85. https://doi.org/10.1016/S0074-7696(05)43 004-1.

55. Beckman BR. Perspectives on concordant and discordant relations between insulin-like growth factor 1 (IGF1) and growth in fishes. Gen Comp Endocrinol. 2011;170(2):233-52. https://doi.org/10.1016/j.ygcen.201 0.08.009.

56. Hasegawa R, Miura T, Kaneko N, Kizaki R, Oishi G, Tanaka H, et al. Production of two recombinant insulin-like growth factor binding protein-1 subtypes specific to salmonids. Gen Comp Endocrinol. 2020;299:113606. https://doi. org/10.1016/j.ygcen.2020.113606.

57. Kamei H, Lu L, Jiao S, Li Y, Gyrup C, Laursen LS, et al. Duplication and diversification of the hypoxia-inducible IGFBP-1 gene in zebrafish. PLoS One. 2008:3(8):e3091. https://doi.org/10.1371/journal.pone.0003091.

58. Salem M, Kenney PB, Rexroad CE, Yao J. Molecular characterization of muscle atrophy and proteolysis associated with spawning in rainbow trout. Comp Biochem Physiol D Genomics Proteomics. 2006;1(2):227-37. https:// doi.org/10.1016/j.cbd.2005.12.003.

59. Salem M, Silverstein J, Rexroad CE, Yao J. Effect of starvation on global gene expression and proteolysis in rainbow trout (Oncorhynchus mykiss). BMC Genomics. 2007;8(1):1-16. https://doi.org/10.1186/1471-2164-8-328.

60. Wilkinson RJ, Porter M, Woolcott H, Longland R, Carragher JF. Effects of aquaculture related stressors and nutritional restriction on circulating growth factors (GH, IGF-I and IGF-II) in Atlantic salmon and rainbow trout. Comp Biochem Physiol A Mol Integr Physiol. 2006;145(2):214-24. https://doi. org/10.1016/j.cbpa.2006.06.010.

61. Duan C, Plisetskaya EM, Dickhoff WW. Expression of insulin-like growth factor I in normally and abnormally developing coho salmon (Oncorhynchus kisutch). Endocrinology. 1995;136(2):446-52. https://doi.org/10.1210/endo.13 6.2.7835275

62. Mommsen TP, Vijayan MM, Moon TW. Cortisol in teleosts: dynamics, mechanisms of action, and metabolic regulation. Rev Fish Biol Fish. 1999; 9(3):211-68. https://doi.org/10.1023/A:1008924418720.

63. Fhlathartaigh MN, McMahon J, Reynolds R, Connolly D, Higgins E, Counihan $T$, et al. Calreticulin and other components of endoplasmic reticulum stress in rat and human inflammatory demyelination. Acta Neuropathol Commun. 2013;1(1):1-15. https://doi.org/10.1186/2051-5960-1-37.

64. Tsai YL, Ha DP, Zhao H, Carlos AJ, Wei S, Pun TK, et al. Endoplasmic reticulum stress activates $S R C$, relocating chaperones to the cell surface where GRP78/CD109 blocks TGF-beta signaling. Proc Natl Acad Sci U S A. 2018;115(18):E4245-54. https://doi.org/10.1073/pnas.1714866115.

65. Nandi A, Yan L, Jana CK, Das N. Role of catalase in oxidative stress-and ageassociated degenerative diseases. Oxid Med Cell Longev. 2019;2019:ID 9613090.

66. Schroeder F, Atshaves BP, McIntosh AL, Gallegos AM, Storey SM, Parr RD, et al. Sterol carrier protein-2: new roles in regulating lipid rafts and signaling. Biochim Biophys Acta Mol Cell Biol Lipids. 2007;1771(6):700-18. https://doi.org/10.1016/j.bbalip.2007.04.005.

67. Wiersma VR, Michalak M, Abdullah TM, Bremer E, Eggleton P. Mechanisms of translocation of ER chaperones to the cell surface and immunomodulatory roles in cancer and autoimmunity. Front Oncol. 2015;5: 7. https://doi.org/10.3389/fonc.2015.00007.

68. Fan Z, Yu P, Wang Y, Wang Y, Fu ML, Liu W, et al. NK-cell activation by LIGHT triggers tumor-specific CD8 T-cell immunity to reject established tumors. Blood. 2006;107(4):1342-51. https://doi.org/10.1182/blood-200508-3485.

69. Smith JA. A new paradigm: innate immune sensing of viruses via the unfolded protein response. Front Microbiol. 2014;5:222. https://doi.org/10.33 89/fmicb.2014.00222.

70. Padmini E, Rani MU. Heat-shock protein 90 alpha (HSP90a) modulates signaling pathways towards tolerance of oxidative stress and enhanced survival of hepatocytes of Mugil cephalus. Cell Stress Chaperones. 2011;16(4): 411-25. https://doi.org/10.1007/s12192-011-0255-9.

71. Kuscuoglu D, Janciauskiene S, Hamesch K, Haybaeck J, Trautwein C, Strnad P. Liver-master and servant of serum proteome. J Hepatol. 2018;69(2):51224. https://doi.org/10.1016/j.jhep.2018.04.018. 
72. Lemmer IL, Willemsen N, Hilal N, Bartelt A. A guide to understanding endoplasmic reticulum stress in metabolic disorders. Mol Metabol. 2021;47: 101169. https://doi.org/10.1016/j.molmet.2021.101169.

73. Kaur J, Debnath J. Autophagy at the crossroads of catabolism and anabolism. Nature Rev Mol Cell Biol. 2015;16(8):461-72. https://doi.org/10.1 038/nrm4024

74. Thiam AR, Farese RV Jr, Walther TC. The biophysics and cell biology of lipid droplets. Nature Rev Mol Cell Biol. 2013;14(12):775-86. https://doi.org/10.103 8/nrm3699.

75. Tocher DR. Metabolism and functions of lipids and fatty acids in teleost fish. Rev Fish Sci. 2003;11(2):107-84. https://doi.org/10.1080/713610925.

76. Zhu S, Tan P, Ji R, Xiang X, Cai Z, Dong X, et al. Influence of a dietary vegetable oil blend on serum lipid profiles in large yellow croaker (Larimichthys crocea). J Agric Food Chem. 2018;66(34):9097-106. https://doi. org/10.1021/acs.jafc.8b03382.

77. Qin G, Xu D, Lou B, Chen R, Wang L, Tan P. iTRAQ-based quantitative phosphoproteomics provides insights into the metabolic and physiological responses of a carnivorous marine fish (Nibea albiflora) fed a linseed oil-rich diet. J Proteome. 2020;228:103917. https://doi.org/10.1016/j.jprot.2020.103917.

78. Tan P, Dong X, Xu H, Mai K, Ai Q. Dietary vegetable oil suppressed nonspecific immunity and liver antioxidant capacity but induced inflammatory response in Japanese sea bass (Lateolabrax japonicus). Fish Shellfish Immunol. 2017;63:139-46. https://doi.org/10.1016/j.fsi.2017.02.006.

79. Koh JH, Wang L, Beaudoin-Chabot C, Thibault G. Lipid bilayer stressactivated IRE-1 modulates autophagy during endoplasmic reticulum stress. J Cell Sci. 2018;131(22). https://doi.org/10.1242/jcs.217992.

80. Hoch FL. Cardiolipins and biomembrane function. Biochim Biophys Acta Rev Biomembr 1992;1113(1):71-133, 1, DOl: https://doi.org/10.1016/0304-41 57(92)90035-9

81. Horvath SE, Daum G. Lipids of mitochondria. Prog Lipid Res. 2013;52(4):590614. https://doi.org/10.1016/j.plipres.2013.07.002

82. Paradies G, Petrosillo G, Paradies V, Ruggiero FM. Mitochondrial dysfunction in brain aging: role of oxidative stress and cardiolipin. Neurochem Int. 2011; 58(4):447-57. https://doi.org/10.1016/j.neuint.2010.12.016.

83. Paradies G, Petrosillo G, Pistolese M, Ruggiero FM. Reactive oxygen species affect mitochondrial electron transport complex I activity through oxidative cardiolipin damage. Gene. 2002;286(1):135-41. https://doi.org/10.1016/S03 78-1119(01)00814-9.

84. Seedorf U, Brysch P, Engel T, Schrage K, Assmann G. Sterol carrier protein X is peroxisomal 3-oxoacyl coenzyme a thiolase with intrinsic sterol carrier and lipid transfer activity. J Biol Chem. 1994;269(33):21277-83. https://doi. org/10.1016/S0021-9258(17)31960-9

85. Frolov A, Miller K, Billheimer JT, Cho T, Schroeder F. Lipid specificity and location of the sterol carrier protein-2 fatty acid-binding site: a fluorescence displacement and energy transfer study. Lipids. 1997;32(11):1201-9. https:// doi.org/10.1007/s11745-997-0154-5.

86. Parentini I, Cavallini G, Donati A, Gori Z, Bergamini E. Accumulation of dolichol in older tissues satisfies the proposed criteria to be qualified a biomarker of aging. J Gerontol A Biol Sci Med Sci. 2005;60(1):39-43. https:// doi.org/10.1093/gerona/60.1.39.

87. Cutler RG, Mattson MP. Sphingomyelin and ceramide as regulators of development and lifespan. Mech Ageing Dev. 2001;122(9):895-908. https:// doi.org/10.1016/S0047-6374(01)00246-9.

88. Hannun YA, Luberto C. Ceramide in the eukaryotic stress response. Trends Cell Biol. 2000;10(2):73-80. https://doi.org/10.1016/S0962-8924(99)01694-3.

89. Andrieu-Abadie N, Gouazé V, Salvayre R, Levade T. Ceramide in apoptosis signaling: relationship with oxidative stress. Free Radic Biol Med. 2001;31(6): 717-28. https://doi.org/10.1016/S0891-5849(01)00655-4.

90. Salvi M, Battaglia V, Brunati AM, La Rocca N, Tibaldi E, Pietrangeli P, et al. Catalase takes part in rat liver mitochondria oxidative stress defense. J Biol Chem. 2007;282(33):24407-15. https://doi.org/10.1074/jbc.M701589200

91. Laurindo FR, Pescatore LA de Castro Fernandes D. Protein disulfide isomerase in redox cell signaling and homeostasis. Free Radic Biol Med. 2012:52(9):1954-69. https://doi.org/10.1016/j.freeradbiomed.2012.02.037.

92. Ali Khan H, Mutus B. Protein disulfide isomerase a multifunctional protein with multiple physiological roles. Front Chem. 2014;2:70.

93. Zeeshan HMA, Lee GH, Kim H, Chae H. Endoplasmic reticulum stress and associated ROS. Int Jo Mol Sci. 2016;17(3):327. https://doi.org/10.3390/ijms1 7030327.

94. Gromova I, Gromov P, Celis JE. Identification of true differentially expressed mRNAs in a pair of human bladder transitional cell carcinomas using an improved differential display procedure. Electrophoresis. 1999;20(2):241-8. https://doi.org/10.1002/(SICI)1522-2683(19990201)20:2<241::AID-ELPS241>3. $0 . \mathrm{CO} ; 2-\mathrm{A}$.

95. Yi Z, Jingting $C, Y u Z$. Proteomics reveals protein profile changes in cyclooxygenase-2 inhibitor-treated endometrial cancer cells. Int J Gynecol Cancer. 2009;19(3)

96. Han D, Xie S, Liu M, Xiao X, Liu H, Zhu X, et al. The effects of dietary selenium on growth performances, oxidative stress and tissue selenium concentration of gibel carp (Carassius auratus gibelio). Aquac Nutr. 2011; 17(3):e741-9. https://doi.org/10.1111/j.1365-2095.2010.00841.x.

97. McCormick SD. Methods for nonlethal gill biopsy and measurement of $\mathrm{Na}$, K -ATPase activity. Can J Fish Aquat Sci. 1993;50(3):656-8. https://doi.org/1 0.1139/ $993-075$.

98. Small BC, Peterson BC. Establishment of a time-resolved fluoroimmunoassay for measuring plasma insulin-like growth factor I (IGF-I) in fish: effect of fasting on plasma concentrations and tissue mRNA expression of IGF-I and growth hormone $(\mathrm{GH})$ in channel catfish (Ictalurus punctatus). Domest Anim Endocrinol. 2005;28(2):202-15. https://doi.org/10.1016/j.domaniend.2004.09. 002.

99. Shimizu M, Swanson P, Fukada H, Hara A, Dickhoff WW. Comparison of extraction methods and assay validation for salmon insulin-like growth factor-I using commercially available components. Gen Comp Endocrinol. 2000;119(1):26-36. https://doi.org/10.1006/gcen.2000.7498.

100. van den Bos R, Althuizen J, Tschigg K, Bomert M, Zethof J, Filk G, et al. Early life exposure to cortisol in zebrafish (Danio rerio): similarities and differences in behaviour and physiology between larvae of the $A B$ and $T L$ strains. Behav Pharmacol. 2019;30(2):260-71. https://doi.org/10.1097/FBP. 0000000000000470

101. Pfaffl MW, Tichopad A, Prgomet C, Neuvians TP. Determination of stable housekeeping genes, differentially regulated target genes and sample integrity: BestKeeper-excel-based tool using pair-wise correlations. Biotechnol Lett. 2004;26(6):509-15. https://doi.org/10.1023/B:BILE.000001 9559.84305.47.

102. Olsvik PA, Lie KK, Jordal AO, Nilsen TO, Hordvik I. Evaluation of potential reference genes in real-time RT-PCR studies of Atlantic salmon. BMC Mol Biol. 2005;6(1):1-9. https://doi.org/10.1186/1471-2199-6-21.

103. Rolland M. Effects of dietary methionine on feed utilization, plasma amino acid profiles and gene expression in rainbow trout (Oncorhynchus mykiss). Technical University of Denmark, National Institute of Aquatic Resources (PhD thesis) 2014

104. Gabillard J, Kamangar BB, Montserrat N. Coordinated regulation of the GH/ IGF system genes during refeeding in rainbow trout (Oncorhynchus mykiss). J Endocrinol. 2006;191(1):15-24. https://doi.org/10.1677/joe.1.06869.

105. Genge CE, Davidson WS, Tibbits GF. Adult teleost heart expresses two distinct troponin C paralogs: cardiac TnC and a novel and teleost-specific ssTnC in a chamber-and temperature-dependent manner. Physiol Genomics. 2013;45(18):866-75. https://doi.org/10.1152/physiolgenomics. 00074.2013 .

106. Christie W, Han X. Lipid Analysis: Isolation, Separation, Identification and Lipodomic Analysis. $4^{\text {th }}$ ed. Oily Press Lipid Library Series; 2010.

107. Folch J, Lees M, Sloane Stanley GH. A simple method for the isolation and purification of total lipides from animal tissues. J Biol Chem. 1957;226(1): 497-509. https://doi.org/10.1016/S0021-9258(18)64849-5.

108. Bylesjö M, Rantalainen M, Cloarec O, Nicholson JK, Holmes E, Trygg J. OPLS discriminant analysis: combining the strengths of PLS-DA and SIMCA Classification. Journal of Chemometrics: A Journal of the Chemometrics Society. 2006;20(8-10):341-51. https://doi.org/10.1002/cem.1006.

109. Wickham H, Chang W. ggplot2. [Computer software]. Retrieved from http:// ggplot2.org 2012

\section{Publisher's Note}

Springer Nature remains neutral with regard to jurisdictional claims in published maps and institutional affiliations. 